\title{
Hydroa vacciniforme-like lymphoma
}

INSERM

\section{Source}

INSERM. (1999). Orphanet: an online rare disease and orphan drug data base. Hydroa vacciniforme-like lymphoma. ORPHA:364039

Hydroa vacciniforme-like lymphoma is a very rare Epstein-Barr virus-associated malignant lymphoproliferative disorder characterized by a chronic, recurrent, vesiculopapular rash, which subsequently ulcerates and scars, located mainly on sunexposed areas and which is associated with systemic manifestations, such as fever, weight loss, asthenia, facial edema, arthralgia, lymphadenopathy, hepatosplenomegaly and/or increased liver enzymes. Hypersensitivity to mosquito bites has been associated and an increased risk of developing systemic lymphoma has been reported. 